\title{
Availability and Utilization of E-Learning Technologies in Teaching Agricultural Science in Senior Schools in Ilorin South L.G.A, Kwara State
}

\author{
*Abdulkareem, M. O. K.O. Afolabi \\ Science Education Department, Faculty of Education, University of Ilorin, Kwara State, Nigeria
}

\begin{abstract}
E-learning technologies are necessary to meet the challenges of the contemporary world education competitiveness in scientific and technological advancement. This study investigated the Availability and utilization of e-learning technologies in teaching agricultural science in senior schools in Ilorin South L.G.A, Kwara State. 60 Agricultural science teachers participated in the study. A researcher-developed forty-five-items questionnaire was used to collect data. Four research questions and two research hypotheses guided the conduct of the study. Data were analyzed using frequency, mean, standard deviation and t-test. Results show that some of the listed e-learning technologies were available for teaching agricultural science in senior schools to a high extent. Some of these include printers, tablets and laptop computers while some like public address system, projectors, interactive whiteboards among others are not available. Results also, revealed that agricultural science teachers use e-learning technologies to a moderate extent. The benefits of e-learning technologies as revealed by the study include for effective classroom management, makes teaching interesting and encourages individual learning among others. Challenges include: lack of functional computer laboratories, inadequate finance, irregular power supply, high cost of e-learning facilities among others. The researchers recommended (among others) that ICT training should be made compulsory for teachers and it should be subsidized by governments, government should incorporate e-learning education into school syllabus, there should be an alternative source of power supply in E-learning libraries in schools.
\end{abstract}

DOI: $10.7176 / \mathrm{JEP} / 12-16-01$

Publication date:June $30^{\text {th }} 2021$

\section{INTRODUCTION}

The rapid development in technology has made great change in the way we live and the social and educational demand of the society. In line with the impact of new technology at work place and everyday life, schools try to improve educational programs and classroom facilities in order to minimize the teaching and learning gap between the present and the future. Information and communication technology has totally impacted its benefits on every society as the highest change agent of human development. Osinem (2008) described ICT as computer propelled tool used by man to process, package and store information. Also, Okenwa (2010) defined ICT as the integration of computer technology mainly in the form of internet and information management to help the users organize, process, analyze, store and retrieve information for use when desired. It entails utilization of communication devices such as cellular phones, radio, computer network, hardware, software, satellite systems as well as various applications associated with them. Advancement in the use of ICT has brought improvement in political, social, economic and educational sector of the nation (Aneke and Udensi, 2017).

The technologies in ICT are very crucial in instructional delivery to enable the students meet up with standard found in other parts of the developed world (Aneke et al., 2017). Ezekoka (2011) stated that use of ICT in education provides effective ways of passing academic instruction, storing, retrieving, encoding and decoding instructions by teachers.

Ugboaja (2011) enumerated some of the information technologies needed for school management to include radio, tape recorder, video tapes, recorder television, calculators and E-learning tools like desktop, laptop, virtual library, printers, internet, school websites, e-mail services, overhead projectors, multimedia examination, scoring power points projectors, opaque projectors, telephone cell phone, digital camera, and scanner. These are required to be adequate so as to enable every student have access to them for learning. The "E-" in E-learning means 'Electronic'. Also, Hamilton and Mbachu (2015) stated that, the field of Information and Communication Technology (ICT) has offered vast opportunities for learning by electronic means, the use of e-learning and internet technology in learning. It is seen as a means to improve accessibility, efficiency and quality teaching. Elearning is simply defined as the application of ICT to the core business of education.

Hedge and Hayward (2004), defined E-learning as an innovative approach for delivering electronically mediated, well-designed, learner-centered and interactive learning environments to anyone, anyplace, anytime by utilizing the internet and digital technologies concerned with instructional design principles. The convergence of the Internet and learning, or Internet enabled learning is called E-learning as opined by Sabina (2008). E-learning as an aspect of ICT is relatively new in Nigeria's educational system. It embraces a wide variety of media 
configurations, including radio, telephone and television broadcast, cable and satellite, Heinich, Molenva Russell \& Smuldina (2002). Teaster \& Blieszer, (1999) were of the view that E-learning has been applied to many institutional methods; however, its primary distinction is that the teacher and the learner are separated in space and possibly time.

The effective utilization of ICT in our schools in the teaching and learning of agricultural science will make teaching no doubt more rewarding. Moreover, children can progress at their own pace in E-learning to master tasks which provide and direct immediate feedback mechanism (Ater, Tiough \& Nerkar, 2005). This can afford the students the opportunity to shape their performance, facilitate a progressive effective group work and increase their social interactive learning (Watson, 2001). Andural and Ikyumen (2006) noted that most teachers do not only lack the skills of operating the computer, they in addition do not know what the computer technology provides to the world. In view of this, Kareem (2004) suggested that training should not be one-shot workshops, but rather ongoing experience so that teachers can be kept up-to date with ever changing technologies.

The Federal Government of Nigeria in the National Policy on Education (FRN 2004) is mindful of the importance of information and communication technology in the world of today that is ICT driven hence its integration in the school curriculum at all levels of education in the country. The document states that government will provide the necessary ICT infrastructure and training needed in the secondary schools. Visits of the researcher to a number of secondary schools in the area of study on teaching practice supervision and indeed schools in other areas show that there is no significant sign that this lofty government policy has been implemented in a state that prides education as its' biggest industry.

On teachers' competence, teachers in Nigerian secondary schools are not competent in basic computer operation and in the use of generic software (Yusuf, 2005), although they have positive attitude towards the use of computer in Nigerian secondary schools. This finding revealed the low level of ICT penetration in the Nigerian school system. This reveals the state of ICT in most of the Nigerian secondary schools. Also, Becta (2004) reported that many teachers who are not skillful in using E-learning tools feel nervous in using it in the class. In addition to this, Balanskat, Blamire and Kefala (2006) found out that teachers do not have extensive knowledge of E-learning which makes them feel uncomfortable in using it effectively in teaching. This study, therefore, examined the availability and utilization of e-learning technologies in teaching Agricultural science in senior schools in Ilorin South L.G.A., Kwara State. The main purpose of the study is to investigate the Availability and Utilization of E-learning Technologies in Teaching Agricultural Science in Senior Schools in Ilorin South L.G.A, Kwara State.

Specifically, the study examined:

i. availability of E-learning technologies in teaching Agricultural science in senior schools.

ii. extent of utilization of E-learning technologies by agricultural science teachers.

iii. benefits of E-learning in teaching of agricultural science.

iv. challenges facing teachers in utilization of E-learning technologies.

v. difference in the perception of challenges facing agricultural science teachers in the utilization of elearning technologies based on gender.

vi. difference in the perception of challenges facing agricultural science teachers in the utilization of elearning technologies based on school type.

The findings from this study would be significant in several ways to the growth and development of senior secondary schools and other institutions in Nigeria. The researcher hopes that the findings of the study will benefit the following bodies such as curriculum planners, school administrators, teachers, students, researchers, examination bodies and parents.

\section{METHODOLOGY}

\section{Research Design}

The research design for the study is a descriptive research of the survey type. This research type is considered appropriate and suitable for this study because it focused on obtaining information and analyzing data from of Agricultural Science teachers on Availability and Utilization of E-learning Technologies in teaching Agricultural Science in Senior Schools in Ilorin South L.G.A, Kwara State.

\section{Population, Sample and Sampling Techniques}

The population for this study was Senior Schools Teachers in both public and private schools in Ilorin South L.G.A, Kwara State. The target populations were Agricultural Science Teachers in the Selected Senior Schools. The choice of senior schools was considered appropriate because agricultural science is taught extensively as stated in the Agricultural Science curriculum. Random Sampling technique was used to draw sample from respondents. The general sample size was determined from the total number of Agricultural Science Teacher in the Selected Senior Schools in the year 2018. The total number of respondents was 60. 


\section{Research Instrument}

This study employed the use of questionnaire as major instrument, it was specifically designed for data collection in the research work called Availability and Utilization of E-learning Technologies in Teaching Agricultural Science Questionnaire (AUETTAS). The questionnaire employed for this study was close-ended type, carefully selected for teachers only. Basically, the questionnaire had five (5) parts namely section A, B, C, $\mathrm{D}$ and $\mathrm{E}$.

Section A consisted of personal characteristics, this section was structured to elicit information about the personal data of the respondents, which are the Agricultural Science teachers to include name of the school, school type, gender, age of teacher, educational qualification, teaching experience. Section B consisted of the statements structured on the availability of E-learning technologies in teaching Agricultural Science. Section C had 10 items seeking information on the level of utilization of E-learning technologies in teaching Agricultural science. Section D consisted of statements structured on the benefits of E-learning technologies in teaching agricultural science, using a four-point Likert- scale, ranging from 4 to 1 'Agree (A); Strongly Agree (SA); Disagree (D) and Strongly Disagree (SD) respectively. Section E consisted of the statements structured on the challenges facing the effective use of E-learning technologies and the suggested solutions. Using a four points Likert- scale, the response to the questionnaire was drawn on response mode categorized as:

$\begin{array}{lll}\text { Strongly Agree } & - & 4 \text { points } \\ \text { Agree } & - & 3 \text { points } \\ \text { Disagree } & - & 2 \text { points } \\ \text { Strongly Disagree- } & 1 \text { point }\end{array}$

\section{Procedure for Data Collection}

The researcher obtained an introductory letter from the Head of Department, Science Education, University of Ilorin, introducing the researcher to various Secondary Schools as a student researcher in the Department. The researcher visited the teachers in their respective schools; explained the purpose of the research, seek for their cooperation and sincere participation in the study. The researcher made it clear to the participating teachers that their contributions will be examined with confidentiality and for the purpose of research only. Thereafter, the researcher questionnaires distributed to them were returned. A total of 60 copies of questionnaire were administered out of which all the 60 copies were returned given a $100 \%$ return rate.

\section{Data Analysis Technique}

The data collected was analyzed using descriptive and inferential statistics. Specifically, the research questions one to four were answered using frequency count, percentage, mean and standard deviation while the two formulated research hypotheses were tested using t-test statistics at 0.05 Alpha level. All the analysis was carried out with the aid of SPSS 22.0 statistical package

\section{DATA ANALYSIS AND RESULTS Demographic Data}

Table 1 shows that 36 respondents were females representing $60 \%$ while 24 were males representing $40 \%$. This implies that majority of the respondents were females.

Table 1 also indicates that 38 respondents were from private schools with percentage of $63.3 \%$ while 22 were from public schools with percentage of $36.7 \%$. This shows that majority of the respondents were from private schools.

Table 1 further shows that 10 respondents with percentage of $16.7 \%$ were within the age of 26-30 years, 21 with percentage of $35 \%$ respondents were within the age of $31-35,9$ respondents with percentage of $15 \%$ were within the age of $36-40,13$ respondents with percentage of $21.7 \%$ were within the age of $41-45$ and 7 with the percentage of $11.7 \%$ were within the age of 46 and above. This shows that majority of the respondents were within the age of 31-35.

In addition, Table 1 indicates that 5 respondents with percentage of $8.3 \%$ were N.C.E. holders, 3 with percentage of $5.0 \%$ were N.D holders, 1 with percentage of $1.7 \%$ was H.N.D holder, 9 with percentage of $15 \%$ were B.Ed holders, 8 with percentage of $13.3 \%$ were B.Sc/ B.Agric holders, 22 with percentage of $36.7 \%$ were B.Sc.(Ed) holders while 12 with percentage of $20.0 \%$ were others. This shows that majority of the respondents were B.Sc.(Ed) holders.

Table 1 indicates that 23 respondents representing 38.3\% have less than 5 years teaching experience, 15 respondents representing 25\% were within 5-9 years of teaching experience while 22 representing $36.7 \%$ were within 10 years and above teaching experience. This indicates that majority of the respondents had less than 5 years of teaching experience. 
Table 1

Demographic Data of the Respondents

\begin{tabular}{|c|c|c|}
\hline Variables & Frequency & Percentage $\%$ \\
\hline \multicolumn{3}{|l|}{ Gender } \\
\hline Female & 36 & 60.0 \\
\hline Male & 24 & 40.0 \\
\hline \multicolumn{3}{|l|}{ School Type } \\
\hline Private & 38 & 63.3 \\
\hline Public & 22 & 36.7 \\
\hline \multicolumn{3}{|l|}{ Age } \\
\hline $26-30$ years & 10 & 16.7 \\
\hline $31-35$ years & 21 & 35.0 \\
\hline $36-40$ years & 9 & 15.0 \\
\hline $41-45$ years & 13 & 21.7 \\
\hline 46 and above & 7 & 11.7 \\
\hline \multicolumn{3}{|c|}{ Highest Educational Qualification } \\
\hline N.C.E & 5 & 8.3 \\
\hline N.D & 3 & 5.0 \\
\hline HND & 1 & 1.7 \\
\hline B.Ed & 9 & 15.0 \\
\hline B.Sc (Agric) & 8 & 13.3 \\
\hline B.Sc $(\mathrm{Ed})$ & 22 & 36.7 \\
\hline Others & 12 & 20.0 \\
\hline \multicolumn{3}{|c|}{ Teaching Experience (in Yrs) } \\
\hline Less than 5 & 23 & 38.3 \\
\hline $5-9$ & 15 & 25.0 \\
\hline 10 and above & 22 & 36.7 \\
\hline
\end{tabular}

Research Question 1: What are the E-learning technologies available in teaching agricultural science in senior secondary schools?

Table 2 depicts findings on the E-learning technologies available for teaching of agricultural science in senior secondary schools. Respondents suggested that items 4, 7 and 9 are the highly available e-learning technology for teaching agricultural science while items $1,2,3,5,6,8,10$ are not available.

Research Question 2: To what extent are E-learning technologies currently used by Agricultural science teachers?

Mean and standard deviation were used to answer this research questions. Since items on extent to which E-learning technologies currently used by agricultural science teachers were structured in a four-response-type (Very High Extent, High Extent, Low Extent and Very Low Extent). 2.5 was used as the baseline for determining participants' responses. Thus, any item whose mean score is equal and above 2.5 signifies the extent to which available E-learning technologies currently used by agricultural science teachers while items whose mean scores are below 2.5 are not. Table 3 depicts item 10 have the highest mean of 3.6 which is e-learning technologies are utilized mainly as public address system for audibility followed by lesson preparation, use of video player in teaching, use of computer laboratory to search for and download materials, scanner is used to copy images, printer is used to print hard copy, Microsoft word is used to type documents, smartphone to search for materials, Google is used to access information with mean of 3.0, 3.0, 3.25, 3.12, 2.98, 2.73, 2.40 and 2.02 respectively. 
Table 2

Availability of E-learning Technologies in Teaching Agricultural Science

\begin{tabular}{|c|c|c|c|c|c|}
\hline Items & $\begin{array}{l}\text { Highly } \\
\text { Available }\end{array}$ & $\begin{array}{l}\text { Moderately } \\
\text { Available }\end{array}$ & $\begin{array}{l}\text { Slightly } \\
\text { Available }\end{array}$ & $\begin{array}{c}\text { Not } \\
\text { Available } \\
\end{array}$ & Remark \\
\hline 1. Projectors & 3 & 18 & 5 & 34 & Not Available \\
\hline 2. PublicAddress System & 3 & 21 & 9 & 27 & Not Available \\
\hline 3. Interactivewhite board & - & 2 & 1 & 57 & Not Available \\
\hline 4. Printers & 20 & 18 & 13 & 9 & Highly Available \\
\hline 5. Virtual library & - & 1 & 1 & 58 & Not Available \\
\hline 6. Internet & 13 & 14 & 13 & 20 & Not Available \\
\hline 7. Tablets & 15 & 6 & 10 & 29 & Highly Available \\
\hline 8. Video player & 11 & 9 & 9 & 31 & Not Available \\
\hline 9. Laptop computer & 21 & 13 & 9 & 17 & Highly Available \\
\hline 10. Audio player & 7 & 10 & 12 & 31 & Not Available \\
\hline
\end{tabular}

Table 3

Extent of Use of E-learning Technologies in Teaching Agricultural Science

\begin{tabular}{|c|c|c|c|c|c|c|}
\hline Items & $\begin{array}{l}\text { Very High } \\
\text { Extent }\end{array}$ & $\begin{array}{l}\text { High } \\
\text { Extent }\end{array}$ & $\begin{array}{l}\text { Low } \\
\text { Extent }\end{array}$ & $\begin{array}{c}\text { Very Low } \\
\text { Extent }\end{array}$ & Mean & SD \\
\hline 1. Computer to teach students & 2 & 9 & 21 & 28 & 3.25 & 0.836 \\
\hline $\begin{array}{l}\text { 2. Smartphone to search for } \\
\text { materials }\end{array}$ & 23 & 17 & 10 & 10 & 2.12 & 1.106 \\
\hline 3. $\begin{array}{l}\text { Microsoft word to type } \\
\text { documents }\end{array}$ & 17 & 13 & 19 & 11 & 2.40 & 1.092 \\
\hline $\begin{array}{l}\text { 4. Computer laboratory to search } \\
\text { for and download materials }\end{array}$ & 7 & 10 & 12 & 31 & 3.12 & 1.075 \\
\hline 5. Google to access information & 26 & 14 & 13 & 7 & 2.02 & 1.066 \\
\hline 6. Scanner to copy images & 9 & 10 & 14 & 27 & 2.98 & 1.112 \\
\hline 7. Printer to print hardcopy & 11 & 14 & 15 & 20 & 2.73 & 1.118 \\
\hline 8. Video player in teaching & 1 & 15 & 9 & 35 & 3.30 & 0.908 \\
\hline 9. Laptop for lesson preparation & 4 & 8 & 14 & 34 & 3.30 & 0.944 \\
\hline 10. Public address system for & 1 & 6 & 9 & 44 & 3.60 & 0.741 \\
\hline
\end{tabular}
audibility while teaching

Research Question 3: What are the benefits of E-learning in teaching agricultural science in secondary schools?

The items on the benefits of E-learning in teaching agricultural science in secondary schools were structured in a four-response-type (Strongly Agree, Agree, Disagree and Strongly Agree). 2.5 was used as the baseline for determining participants' responses. Thus, any item whose mean score is equal and above 2.5 signifies the benefits of E-learning in teaching agricultural science in secondary schools while items whose mean scores are below 2.5 are not. Table 4 depicts that all the listed items are the benefits of E-learning in teaching agricultural science in secondary schools.

Research Question 4: What are the challenges facing agricultural science teachers in the utilization of Elearning technologies?

The items on the challenges facing agricultural science teachers in the utilization of E-learning technologies were structured in a four-response-type (Strongly Agree, Agree, Disagree and Strongly Agree). 2.5 was used as the baseline for determining participants' responses. Thus, any item whose mean score is equal and above 2.5 signifies the benefits of challenges facing agricultural science teachers in the utilization of E-learning technologies while items whose mean scores are below 2.5 are not. Table 5 depicts that all the listed items are the challenges facing agricultural science teachers in the utilization of E-learning technologies. 
Table 4 Benefits of E-learning in Teaching Agricultural Science

\begin{tabular}{|c|c|c|c|c|c|c|}
\hline Items & SA & $\mathbf{A}$ & $\mathbf{D}$ & SD & Mean & SD \\
\hline 1. Improve students' performance & 33 & 26 & 1 & - & 3.10 & 0.536 \\
\hline 2. Help teachers to demonstrate concepts & 29 & 27 & 4 & - & 2.99 & 0.619 \\
\hline 3. Effective teaching will be achieved & 32 & 26 & 2 & - & 3.08 & 0.567 \\
\hline 4. Make teaching more interesting & 28 & 28 & 4 & - & 2.97 & 0.616 \\
\hline 5. Make it easy to control large class & 22 & 30 & 8 & - & 2.66 & 1.73 \\
\hline 6. Creates greater opportunity for interactive learning & 23 & 31 & 5 & 1 & 2.58 & 0.686 \\
\hline 7. Provision of access to unlimited information & 27 & 28 & 3 & 2 & 2.57 & 0.729 \\
\hline 8. Enables learner to learn at his own pace & 26 & 30 & 4 & - & 2.75 & 0.610 \\
\hline 9. Serve as motivating factor in teaching & 23 & 32 & 4 & 1 & 2.72 & 0.666 \\
\hline 10. Assist learners to develop problem solving skills & 20 & 35 & 5 & - & 2.75 & 0.600 \\
\hline 11. Makes it easy to achieve lesson objectives & 25 & 26 & 5 & 4 & 2.80 & 0.860 \\
\hline
\end{tabular}

Table 5

Challenges Facing Agricultural Science Teachers in the Utilization of E-learning Technologies

\begin{tabular}{|c|c|c|c|c|c|c|}
\hline Items & $\mathbf{S A}$ & $\mathbf{A}$ & D & SD & Mean & SD \\
\hline 1. Lack of functional computer laboratory & 35 & 24 & 1 & - & 2.43 & 0.533 \\
\hline 2. Time constraints in using e-learning facilities & 15 & 32 & 9 & 1 & 2.93 & 0.686 \\
\hline 3. Insufficient computer peripheral & 29 & 30 & 1 & - & 2.55 & 0.594 \\
\hline 4. Inadequate computer by teachers & 23 & 34 & 3 & - & 2.67 & 0.572 \\
\hline 5. Availability of pornographic sites & 28 & 27 & 5 & - & 2.62 & 0.640 \\
\hline 6. Low computer literacy level of teachers & 18 & 31 & 10 & 1 & 2.90 & 0.730 \\
\hline 7. Underfunding from government & 27 & 31 & 1 & 1 & 2.60 & 0.616 \\
\hline 8. Irregular power supply & 26 & 31 & 2 & 1 & 2.63 & 0.637 \\
\hline 9. High cost of e-learning facilities & 33 & 22 & 4 & 1 & 2.55 & 0.699 \\
\hline 10. Lack of internet facilities in schools & 29 & 28 & 2 & 1 & 2.58 & 0.645 \\
\hline 11. Poor physical infrastructure & 25 & 30 & 4 & 1 & 2.68 & 0.676 \\
\hline 12. Frequent breakdown of e-leaning facilities & 20 & 30 & 7 & 3 & 2.88 & 0.804 \\
\hline 13. Inadequate finance for monthly subscription & 23 & 28 & 9 & - & 2.77 & 0.698 \\
\hline 14. Inadequate ICTs training for teachers & 27 & 26 & 6 & 1 & 2.68 & 0.725 \\
\hline
\end{tabular}

\section{Research Hypotheses}

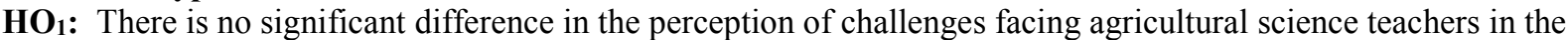
utilization of E-learning technologies based on gender.

From Table 6, analysis reveals that Cal. t-value of 0.526 and p-value of 0.601 . The p-value is greater than the alpha 0.05 alpha level, therefore, hypothesis one was not rejected. In view of this, it means there is no significant difference in the perception of challenges facing agricultural science teachers in the utilization of Elearning technologies based on gender.

Table 6

T-Test Analysis on Difference in the Perception of Challenges Facing Agricultural Science Teachers in the Utilization of E-learning Technologies based on Gender

\begin{tabular}{|c|c|c|c|c|c|c|c|}
\hline Gender & $\mathbf{N}$ & Mean & SD & Cal. t- value & Df & Sig. (2- tailed) & Decision \\
\hline \multirow[t]{2}{*}{ Male } & 36 & 23.78 & 5.535 & & & & \\
\hline & & & & 0.538 & 58 & 0.601 & Not Rejected \\
\hline Female & 24 & 23.04 & 4.947 & & & & \\
\hline
\end{tabular}

$\mathbf{H O}_{2}$ : There is no significant difference in the perception of challenges facing agricultural science teachers in the utilization of E-learning technologies based on school type.

From Table 7, analysis reveals that Cal. t-value of 1.100 and p-value of 0.276 . The p-value is greater than the alpha 0.05 alpha level, therefore, hypothesis two was not rejected. In view of this, it means there is no significant difference in the perception of challenges facing agricultural science teachers in the utilization of Elearning technologies based on school type. 
Table 7: T-Test Analysis on Difference in the Perception of Challenges Facing Agricultural Science Teachers in the Utilization of E-learning Technologies based on School Type

\begin{tabular}{lccccccc}
\hline School type & N & Mean & SD & Cal. t- value & Df & Sig. (2- tailed) & Decision \\
\hline Private & 38 & 24.05 & 5.680 & & 58 & 0.276 & Not Rejected \\
\multirow{2}{*}{ Public } & & & & 1.100 & & & \\
\hline
\end{tabular}

\section{Summary of Major Findings}

The following are major findings:

1. Printer, tablets and laptop computer are the highly available e-learning technologies for teaching of agricultural science while projector and public address system among others are not available.

2. The e-learning technologies are utilized as public address system for audibility among others while teaching agricultural science.

3. Benefits of e-leaning technologies in teaching agricultural science includes: achievement of effective teaching and for classroom management among others.

4. The challenges facing agricultural science teachers in the utilization of E-learning technologies include lack of functional computer laboratory among others.

5. There is no significant difference in the perception of challenges facing agricultural science teachers in the utilization of E-learning technologies based on gender.

6. There is no significant difference in the perception of challenges facing agricultural science teachers in the utilization of E-learning technologies based on school type.

\section{DISCUSSION, CONCLUSION AND RECOMMENDATIONS}

This chapter presents the discussion of findings, the conclusion derived from the discussion, the recommendations as well as suggestions for further studies on the research carried out on availability and utilization of e-learning technologies in teaching Agricultural Science in senior schools in Ilorin South Local Government Area, Kwara State. Nigeria.

\section{Discussion}

The discussion of this study appraised the availability and utilization of e-learning technologies in teaching agricultural science in senior schools in Ilorin South L.G.A. The finding revealed that printer, tablets and laptop computer were the highly available e-learning technologies for teaching agricultural science. The study agrees with the study of Gabadeen, Alabi, \& Akinnubi (2015) which stated that e-learning technologies were relatively available to the teachers.

Also, the findings revealed that e-learning technologies are utilized as public address system for audibility, laptop for lesson preparation, video player in teaching, computer to teach students, computer to search for and download materials, scanner to copy images, printer to print hardcopy, Microsoft word to type documents, google to search for materials and access information. This study agrees with the study of Gabadeen, Alabi and Akinnubi (2015) which stated that e-learning technologies are fairly utilized by teachers.

The finding further showed that the topmost benefits of E-learning in teaching agricultural science are; it makes it easy to achieve lesson objectives, for effective classroom management, assist learners to develop problem solving skills, creates greater opportunity for interactive learning, serve as motivating factor in teaching, provision of access to unlimited information, enables learner to learn at his own pace, make teaching more interesting, help teachers to demonstrate concepts, effective teaching will be achieved and improve students' performance. This finding gives credence to the work of Aboderin \& Kumuyi (2013) who stated that using elearning makes it easy to control large class, it enables the learner to learn at his own pace/encourages individual learning, it makes teaching and learning effective and efficient. This finding is also in line with the work of Torruam (2012) who opined that e-learning technology can increase learner motivation as it combines the media richness and interactivity of other ICTs with the opportunity to connect with real people and to participate in real world events. In addition, the finding from the study depicts that the challenges facing agricultural science teacher in the utilization of E-learning technologies include; low computer literacy level of teachers, inadequate ICTs training for teachers, availability of pornographic sites, poor physical infrastructure, frequent breakdown of e-leaning facilities, inadequate finance for monthly subscription, insufficient computer peripheral, inadequate computer by teachers, time constraints in using e-learning facilities, lack of internet facilities in schools, high cost of e-learning facilities, underfunding from government, irregular power supply and lack of functional computer laboratory are also the challenges facing agricultural science teacher in the utilization of E-learning technologies. This finding gives credibility to the work of Torruam (2012) who noted that the challenges facing the development of e-learning in education are; limited qualified teachers to teach ICT in schools, inadequacy of 
computers, incessant supply of electricity, high cost of computers in Nigeria, broken down computers and burglary.

There was no significant difference in the perception of challenges facing agricultural science teachers in the utilization of E-learning technologies based on gender. This finding is in contrary to the work of Aduwa and Iyamu (2004) who stated that there is significant difference between male and female perception in the challenges facing teachers in the utilization of E-learning technologies. There was no significant difference in the perception of challenges facing agricultural science teachers in the utilization of E-learning technologies based on school type. This finding is in accordance to the findings of Aduwa and Iyamu (2004) who opined there is private schools differ from public schools in their perception of challenges teachers in the utilization of Elearning technologies.

\section{Conclusion}

From the finding of the study, it can be concluded that printer and projectors among others are available for teaching agricultural science in senior schools while interactive white board, among others are not available for teaching in senior schools. It can be concluded that e-learning technologies is used as video player in teaching agricultural science among others.

In addition, it can be concluded that the benefits of E-learning in teaching Agricultural Science among others is the provision of access to unlimited information. The challenges facing Agricultural Science teachers in the utilization of E-learning technologies include low computer literacy level of teachers and inadequate ICTs training for teachers among others.

Conclusively, there is no significant difference in the perception of challenges facing agricultural science teachers in the utilization of E-learning technologies based on school type and gender.

\section{Recommendations}

The following recommendations were made based on the findings of this study:

1. ICT training should be made compulsory for teachers and it should be subsidized by governments.

2. There should be provision of more computer systems in schools as well as proper funding and encouraging teachers for ICT training.

3. Government should incorporate e-learning facilities into school syllabuses.

4. Seminars and trainings should be organized to enlighten both staffs and students on the effectiveness of E-learning.

5. There should be awareness programme on the use of E-learning technologies.

6. There should be an alternative source of power supply in E-learning libraries in schools.

\section{Suggestions for Further Studies}

This study was carried out on availability and utilization of e-learning technologies in teaching Agricultural Science in senior schools in Ilorin South Local Government Area, Kwara State. However, the researcher fervently suggests that further studies should be done on a larger population covering other related subjects and school types.

\section{REFERENCES}

Aboderin, S.O. \& Kumuyi, G.J. (2013). The problems and prospects of e-learning in curriculum implementation in secondary schools in Ondo State. Nigeria. International Journal of Educational Research and Technology. Vol. 4.March 2013: 90-96

Aduwa-Ogiegbaen, S.E. \& Iyamu, E.O.S. (2005). Using information and communication technology in secondary schools in Nigeria: Problems and prospects. Educational Technology and Society, 8(1): 104-112.

Andural, S. I., \& Ikyumen, M. (2006). The use of information technology in the teaching/learning of vocational and technical education in Nigeria. Benue State Journal of education 1(7) 53-59.

Aneke, C.U. (2015). Assessment of methods used by agricultural science teachers in instructional delivery in secondary schools in Enugu State. British Journal of Education. www.bje.org.com. 3(11) 97-206.

Aneke, C. U. \& Udensi, G. O. (2017). Integrity Information and Communication Technology in teaching agriculture in secondary schools in Enugu state. Journal of Research in science and Technology Education. Vol.6 No. 1, 2016.

Balanskat, A., Blamire, R., \& Kefala, S. (2006). A review of studies of ICT impact on schools in Europe: European School net

Becta, (2004). A review of the research literature on barriers to the uptake of ICT by Teachers. Retrieved August 13, 2008, from http://www.becta.org.uk

Federal Republic of Nigeria (2004). National policy on education. 4th ed. Lagos: Nigerian Educational Research and Development Council. 
Gabadeen, W.O. Alabi, A.T. \& Akinnubi,O.P. (2015). Availability, accessibility and utilization of e-Learning technologies for sustainable secondary education in Federal Capital Territory, Abuja-Nigeria. Asia Pacific Journal of Education, Arts and Sciences, Vol. 2 No. 2, April 2015.

Hamilton Ekeke, J.T. \& Mbachu, C. E. (2015). The place of Information, Communication and Technology (ICT) in teaching and learning in Nigeria Tertiary Institution. American journal of Educational Research (3) 340347.

Hedge, N. \& Hayward, L. (2004). Redefining roles. University e-learning contributing to Lifelong learning in a networked world. E-Learning, 1:128 - $145 \mathrm{http}$ ://www.nationmaster.com/country/ni/Internet

Heinich, R., Michael, M., James, D. R., \& Sharon, E. S. (2002). Instructional media and technologies for learning (7th Edition). Ohio, Pearson Education, Inc., pp. 286 - 299.

Millennium Development Goals. Fiji National Reports, National planning Office, Ministry of Finance and National Planning November 2004.

Nigerian Educational Research and Development Council (NERDC). Senior secondary school e-curriculum agricultural science for SS 1-SS 3: 2012.

Nigeria (2007). National policy on education. Federal Government press, Federal republic of Nigeria (1981) 21 June, 2007.

Okenwa, G. N. (2008). Meeting the challenges of information technology: case for reform in distance education programme. Proceedings of first International Conference of the faculty of Education, University of Nigeria Nsukka. $197-202$.

Sabina N. (2008): Challenges in the application Of e-Learning by secondary school teachers in Anambra State, Nigeria, Nnamdi Azikiwe University, Nigeria.

Teaster \& Blieszer (1999). in Foster, A. (2005). Realising the potential - A review of the future role of further education colleges (Foster Report). London: DfES.

Toruam, J.A. (2012). Application of e-teaching and e-learning in Nigerian education system. Academic Research International, Vol. 3, No.1, July 2012

Ugboaja C.I (2011). Information and Communication Technology utilization in human capital development in agriculture education Zone Umuahia. Ladies of Ivory Tower (LIT) Journal. 1(2) 129-135.

Yusuf, M.O. (2005). An investigation into teachers self-efficacy in implementing computer education in Nigerian secondary schools. Retrieved 8th May 2006 from http://www.nCSU.Edu.Meridian/sum 2005/computered Nigerian schools. page $-5 . h$ tm

Watson, D. M. (2001). Pedagogy before technology: Rethinking the relationship between ICT and teaching. Journal of Education and Information Technologies 6(4), 257-266. 